\title{
The Investigation and Study on the Current Situation of College Aesthetics Education
}

\author{
Xin Guan \\ The art center of Bohai university ,jinzhou Liaoning province
}

2927496295@qq.com

\section{Keywords: College aesthetics; Current situation; Countermeasures}

\begin{abstract}
Aesthetic education, the full name is aesthetic education or beauty education, Referring to under the guidance of the basic theory of aesthetics education, through natural beauty, social beauty, artistic beauty, we can carry out aesthetic education activities, aiming at establishing a correct aesthetic concept, forming healthy aesthetic taste and noble aesthetic ideal, so as to cultivate sentiment, improve people' ability to feel the beauty, appreciate the beauty, distinguish the beauty and create beauty. Therefore, aesthetic education occupies a very important and special status in the quality education system, has an important significance in cultivating a comprehensive development of talent. Higher education is the basic project of cultivating talents, and also the best stage of aesthetic education. It is necessary to strengthen the teaching of aesthetic education in colleges under the concept of quality education, so as to achieve the goal of beauty to moral education, beauty to wisdom, beauty to labor and beauty to health, In the aesthetic students are deeply thought the purpose of ideological education.
\end{abstract}

\section{Statement of Problem}

Research Background. Aesthetic education, the full name is aesthetic education or beauty education. In our living society, true and false coexist, good and evil company with our life. In such a complex society how people should make their own correct value orientation, what criteria to distinguish what is true, good, beauty and which is false, evil, ugly, and how to consciously love and praise the truth, good, beauty and abandon fake, evil, ugly things? In education, that have always been our focus. "Aesthetic education is not only able to cultivate students with noble sentiment, but also to stimulate students to learn vitality, promote intellectual development, develop students' innovative ability." Aesthetic education has a great connection with our life and learning, said the Ministry of Education " the 21 st century education revitalization action plan ". Life itself is beautiful, is created for us, is human crystallization in the era of hard work, determining everyone need to find the beautiful thing in our life and learning, to feel life, feel nature, feel life. While education, aiming at entertaining in the pleasure, entertaining in the beauty to enjoy, entertaining in the beautiful impression.

Research Assumptions. I believe that students with differently cultural level, professional orientation, gender, urban and rural gap will lead to students have a different understanding of the aesthetic. To this end, the author treat students from Bohai University as the main survey object. Issue respectively a questionnaire to different grades, different undergraduate and graduate students, in order to understand relationship between the students' cultural level, professional orientation and other aspects of the students with the actual situation of accepting the aesthetic education.

Therefore, the hypothesis of this study is that the students with different grades, different professions, different sexes, students will have different situation in aesthetics.

\section{Research tools}

Questionnaire. The author has compiled the questionnaire on the situation of college students' aesthetic education, which mainly examines the reality of aesthetic education accepted by the respondents. The questionnaire includes basic information and aesthetic education related to the 
reality of the two parts: the basic information including grade, gender, professional and students four areas, and the main part of the questionnaire consists of 25 questions.

Questionnaire Issue and Data Analysis. The scope of the survey includes undergraduate and postgraduate students. The author issued the questionnaires at Harbin Normal University. A total of 300 questionnaires were collected, of which 280 were valid questionnaires.

The questionnaire information was recorded and analyzed using SPSS data analysis software.

This analyzes apply statistical principles, using frequency analysis, reliability analysis, factor analysis and variance analysis and other methods, respectively, to investigate the demographic information of respondents, questionnaire reliability, research dimensions and differences test.

\section{Research Results}

\section{Population Statistics Information of Respondent}

Table 1 Class

\begin{tabular}{|ll|l|l|l|l|}
\hline & & Frequency & Percent & Valid Percent & Cumulative Percent \\
\hline Valid & Freshman & 86 & 30.7 & 30.7 & 30.7 \\
& Sophomore & 132 & 47.1 & 47.1 & 77.9 \\
& Junior & 15 & 5.4 & 5.4 & 83.2 \\
Senior & 15 & 5.4 & 5.4 & 88.6 \\
Postgraduate one & 24 & 8.6 & 8.6 & 97.1 \\
Postgraduate two & 7 & 2.5 & 2.5 & 99.6 \\
Postgraduate three & 1 & .4 & .4 & 100.0 \\
Total & 280 & 100.0 & 100.0 & \\
\hline
\end{tabular}

A total of 280 valid questionnaires were collected. Of which 101 freshman students accounted for $30.7 \%$ of the total; 132 sophomore students accounted for $47.1 \%$ of the total; 15 junior students 15 accounted for $5.4 \%$ of the total; 15 senior students accounted for the total number of $5.4 \% ; 24$ postgraduate one student accounted for $8.6 \% ; 7$ postgraduate two students accounted for $2.5 \%$ of the total; 1 postgraduate three student accounted for a total of $0.4 \%$

Table 2 Gender

\begin{tabular}{|ll|l|l|l|l|}
\hline & & Frequency & Percent & Valid Percent & Cumulative Percent \\
\hline \multirow{2}{*}{ Valid } & Male & 30 & 10.7 & 10.7 & 10.7 \\
& Female & 250 & 89.3 & 89.3 & 100.0 \\
& Total & 280 & 100.0 & 100.0 & \\
\hline
\end{tabular}

In the effective questionnaires, there were 30 boys accounted for $10.7 \%$ of the total, 250 girls accounting for $89.3 \%$ of the total. Because the questionnaire are issued by teachers in colleges, so the number of boys are much less, the number of girls are more.

Table 3 Major classification

\begin{tabular}{|c|c|c|c|c|c|}
\hline & & Frequency & Percent & Valid Percent & $\begin{array}{l}\text { Cumulative } \\
\text { Percent }\end{array}$ \\
\hline \multirow[t]{4}{*}{ Valid } & Liberal art & 107 & 38.2 & 38.2 & 38.2 \\
\hline & Science & 89 & 31.8 & 31.8 & 70.0 \\
\hline & Art & 84 & 30.0 & 30.0 & 100.0 \\
\hline & Total & 280 & 100.0 & 100.0 & \\
\hline
\end{tabular}


In the effective questionnaires, the number of liberal arts were 107 students accounted for $38.2 \%$ of the total; 89 science students accounted for 31.8\% of the total; 84 art students accounted for $30 \%$ of the total.

Table 4 Students resource

\begin{tabular}{|ll|l|l|l|l|}
\hline & & & & & $\begin{array}{l}\text { Cumulative } \\
\text { Percent }\end{array}$ \\
& & Frequency & Percent & Valid Percent & 64.6 \\
Valid & Towns & 181 & 64.6 & 64.6 & 100.0 \\
& Villages & 99 & 35.4 & 35.4 & \\
\hline & Total & 280 & 100.0 & 100.0 & \\
\hline
\end{tabular}

Among the valid questionnaires collected, the number of students from urban areas was 181, accounting for $64.6 \%$ of the total, and the number of students from rural areas was 99 , accounting for $.4 \%$ of the total.

\section{Analysis on Reliability Confidence Level}

Table 5 Case Processing Summary

\begin{tabular}{|ll|l|l|}
\hline & & $\mathrm{N}$ & $\%$ \\
\hline Cases & Valid & 279 & 99.6 \\
& Excluded $^{\mathrm{a}}$ & 1 & .4 \\
& Total & 280 & 100.0 \\
\hline
\end{tabular}

a. Listwise deletion based on all variables in the procedure.

Of the 280 questionnaires recovered and entered, 279 valid questionnaires were valid, one is missing. The whole questionnaires had a single alpha coefficient of 0.858 , and the reliability was very good and could continue to be analyzed.

Join multiple choice questions to carry out the reliability analysis, the Alpha coefficient is 0.812

\section{Factors Analysis}

Table 6 KMO and Bartlett's Test

\begin{tabular}{|c|l|l|}
\hline \multicolumn{2}{|l|}{ Kaiser-Meyer-Olkin Measure of Sampling Adequacy. } & .866 \\
Bartlett's Test of Sphericity $\quad$ Approx. Chi-Square & 2195.771 \\
& Df & 276 \\
& Sig. & .000 \\
\hline
\end{tabular}

The initial KMO value is 0.866 , meaning that it could be the factor to be analyzed

According to the table, it can be seen that the cumulative interpretation rate is 56.388 , reaching to the standard, the analysis can be carried out from four dimensions.

Dimension one: The current situation of degree of emphasis on aesthetics education for schools and teachers

The Alpha value of the current situation of degree of emphasis on aesthetics education for schools and teachers is 0.827 , could be carried out to do variance analysis.

Dimension two: The recognition of current situation on aesthetics education for students.

The Alpha value of the recognition of current situation on aesthetics education for students is 0.748 , could be carried out to do variance analysis.

Dimension three: The current implementation situation of aesthetic education.

The Alpha value of the current implementation situation of aesthetic education is 0.717 , could be carried out to do variance analysis 
Dimension four: The current situation of course setting of school aesthetic education

The Alpha value of the current situation of course setting of school aesthetic education is 0.104 , because of the orders of choices setting, so the Alpha value is low, having no impact on the research.

\section{Variance Analysis}

(1) Grade difference

The Sig values are less than 0.05 , indicating that there is a significant difference between the learners of different grades in terms of the importance of schools and teachers for aesthetic education, the students' understanding of beauty, the implementation of aesthetic education, and the understanding of course setting of school aesthetic education.

The difference of majors

The Sig values are less than 0.05 , indicating that there is a significant difference between the learners of different grades in terms of the importance of schools and teachers for aesthetic education, the students' understanding of beauty, the implementation of aesthetic education, and the understanding of course setting of school aesthetic education.

The Sig values are larger than 0.05 , indicating that there is no significant difference between the learners of different grades in terms of the importance of schools and teachers for aesthetic education, the students' understanding of beauty, the implementation of aesthetic education, and the understanding of course setting of school aesthetic education.

\section{Correlation Analysis}

Table 7 Correlations

\begin{tabular}{|c|c|c|c|c|}
\hline & $\begin{array}{l}\text { The current } \\
\text { situation of degree } \\
\text { of emphasis for } \\
\text { schools and } \\
\text { teachers }\end{array}$ & $\begin{array}{l}\text { The recognition of } \\
\text { current situation of } \\
\text { for students }\end{array}$ & $\begin{array}{l}\text { The current } \\
\text { implementation } \\
\text { situation of } \\
\text { aesthetic education }\end{array}$ & $\begin{array}{l}\text { The current } \\
\text { situation of } \\
\text { course setting of } \\
\text { school aesthetic } \\
\text { education }\end{array}$ \\
\hline $\begin{array}{l}\text { The current situation Pearson Correlation } \\
\text { of degree of Sig. (2-tailed) } \\
\text { emphasis for schools } \mathrm{N} \\
\text { and teachers }\end{array}$ & 280 & $\begin{array}{l}.475^{* *} \\
.000 \\
280\end{array}$ & $\begin{array}{l}.529^{* *} \\
.000 \\
280\end{array}$ & $\begin{array}{l}.358^{* *} \\
.000 \\
279\end{array}$ \\
\hline $\begin{array}{l}\text { The recognition of Pearson Correlation } \\
\text { current situation of Sig. (2-tailed) } \\
\text { for students } \\
\end{array}$ & $\begin{array}{l}.475^{* *} \\
.000 \\
280 \\
\end{array}$ & $\begin{array}{l}1 \\
280 \\
\end{array}$ & $\begin{array}{l}.461^{* *} \\
.000 \\
280 \\
\end{array}$ & $\begin{array}{l}.215^{* *} \\
.000 \\
279 \\
\end{array}$ \\
\hline $\begin{array}{l}\text { The current Pearson Correlation } \\
\text { implementation } \quad \text { Sig. (2-tailed) } \\
\text { situation of aesthetic } \mathrm{N} \\
\text { education }\end{array}$ & $\begin{array}{l}.529^{* *} \\
.000 \\
280\end{array}$ & $\begin{array}{l}.461^{* *} \\
.000 \\
280\end{array}$ & 280 & $\begin{array}{l}.242^{* *} \\
.000 \\
279\end{array}$ \\
\hline $\begin{array}{l}\text { The current situation Pearson Correlation } \\
\text { of course setting of Sig. (2-tailed) } \\
\text { school aesthetic } \mathrm{N} \\
\text { education }\end{array}$ & $\begin{array}{l}.358^{* *} \\
.000 \\
279\end{array}$ & $\begin{array}{l}.215^{* *} \\
.000 \\
279\end{array}$ & $\begin{array}{l}.242^{* *} \\
.000 \\
279\end{array}$ & 1 \\
\hline
\end{tabular}

**. Correlation is significant at the 0.01 level (2-tailed).

We can see that the Pearson coefficient of the student's cognition of beauty and the attitude towards the ugly Mona Lisa on the network is 0.204 . The probability of the significance test is Sig $=0.001$, and the total number of date is 280 .

From the above chart we can see that students in the classroom to experience the beauty of the situation and through the professional learning area to create the beauty, the Pearson coefficient is 
0.362. The probability of significant test $\mathrm{Sig}=0.000$, involved in the calculation of a total of 280 pairs of data.

\section{Multiple Choice Statistics Analysis}

Table 8 Case Summary

\begin{tabular}{|c|c|c|c|c|c|c|}
\hline & \multicolumn{6}{|c|}{ Cases } \\
\hline & \multicolumn{2}{|l|}{ Valid } & \multicolumn{2}{|c|}{ Missing } & \multicolumn{2}{|c|}{ Total } \\
\hline & $\mathrm{N}$ & Percent & $\mathrm{N}$ & Percent & $\mathrm{N}$ & Percent \\
\hline$\$ S a^{a}$ & 280 & $93.0 \%$ & 21 & $7.0 \%$ & 301 & $100.0 \%$ \\
\hline$\$ S b^{a}$ & 280 & $93.0 \%$ & 21 & $7.0 \%$ & 301 & $100.0 \%$ \\
\hline
\end{tabular}

a. Dichotomy group tabulated at value 1 .

From the table we can be seen that, the students who usually like to see literary theory, aesthetics, literature and art books accounted for $10.1 \%$ of the total number of students.

From the above table, we can see that the number of people who choose "good heart" is $17.7 \%$ of the total number; the number of people who choose "sincerely with others" is $15.4 \%$ of the total number; the number of people who choose "willing to help others" is $13.7 \%$ of the total number; the number of people who choose "humor and funny" is $12.0 \%$ of the total numbe.

From the table we can see that students who choose aesthetics, art books are 74 students, therein boys are 10 people and girls 64 people. The boys who in the choice of aesthetics literary and artistic books accounted for $33.3 \%$ of the total number of boys, girls who in the choice of aesthetics, art classes accounted for $25.6 \%$ of the total number of girls.

\section{Gender*\$Sb Crosstabulation}

From the table we can see that in the boys group, the boys who choose "good heart" accounted for $80 \%$ of the total number of boys; choose "sincerely with others" accounted for $60.0 \%$ of the total number of boys; choose "love their parents" accounted for 56.7\% of the total number of boys; choose "willing to help others" accounted for $53.3 \%$ of the total number. In the group of girls, the girls who choose "good-hearted" students accounted for $84.4 \%$ of the total number of girls; choose "sincerely with others" accounted for $74.8 \%$ of the total number of girls; choose "humor and funny" accounted for $58.8 \%$ of the total number of girls.

From the table we can see that different major students focusing on the highest quality choices in the choice of friends are "good heart" accounted for $84.1 \%, 80.9 \%, 86.9 \%$ respectively, of the total number of majors categories

As the above table we can be seen that among the students who read books related to aesthetics, $27.6 \%$ of the total number of 50 students from urban students and $24.2 \%$ of the total number of 24.2 students from rural areas.

From the above table we can see that freshman students mainly read cartoons, cartoon animal, martial arts, romantic story, fantasy and other entertainment books; sophomore students mainly read newspapers, magazines; junior students mainly reading literature, masterpiece; postgraduate one mainly read education, teaching, research bibliography or articles; postgraduate two mainly read education, psychology, teaching, research bibliography or articles.

\section{Summary}

China's aesthetic education activities can't be got comprehensive and perfect development, the main reason is the lack of correct theoretical guidance, no education research results can be for reference, coupled with the school teachers themselves without high quality, resulting in school aesthetic education effect can not be sublimated. As the research in this paper, first of all, establishing the important position for aesthetic education in China's quality education, so that 
school educators updated the traditional concept of education, treating aesthetic education as an important part of quality education, carrying out planned, purposeful and systematic ways to exhibit the effect and function of the overall effect of aesthetic education in the implementation of quality education, promoting the interaction and comprehensive integration between the aesthetic quality with ideological and moral quality, intelligent quality, physical quality and the quality of labor and technology, which constitute the overall quality of student training structure, better to carry out quality education. Secondly, through the analysis of the problems and causes in the present situation of the aesthetic education of college students in China, this paper point out the weaknesses and development directions that the Chinese universities need to overcome in the future. On the basis of further clarifying the educational tasks, goals and contents, in addition the problems of status, role and tasks of aesthetic education in the quality of education, re-understanding and recognize the consistency of education, quality education, aesthetic education of the ultimate goal, in order to facilitate the correct implementation of quality education and the healthy development of school aesthetic education. Finally, through the study on perfecting the aesthetic education of college, the author established for the school to establish the metaphor, the task, the classification stratification goal, the curriculum, the method, the way, the environment, the team, the management, the assessment, and the adaptation time, space and other variety of organic elements, put forward the controllable, feasible and measurable aesthetic education independent entities, to promote the students to get all-round, multi-channel aesthetic education, having an important significance on improving the comprehensive ability of quality education and achieving high efficiency education.

\section{Project Fund}

"A study on the path of improving the students' subjectivity in the interactive course of vocal music in Colleges and universities from the perspective of the classroom" of 2016 Bohai university.

\section{References}

[1] Cui Hongdi. The application of spss in education and psychological statistics [M]. Harbin: Heilongjiang Education Press, 2002

[2] Zhu Guangqian. Talk about the beauty [M]. Beijing: Beijing Press, 2012, 1

[3] Yuan Shuya, Ma Changsheng. Aesthetic education tutorial [M]. Kaifeng: Henan University Press, 1991, 8

[4] Dabney Thomson, Wang Ke-ping translator. Introduction to aesthetics [M]. Beijing: Higher Education Press, 2005, 11

[5] Yang Xiangtao, Chen Shiming. Investigation and analysis of the status quo of aesthetic education in middle school chemistry teaching [J]. Chemistry Education, 2007, 2

[6] Jiang Huan. Exploration of aesthetic education in colleges [J]. Quality Education and Educational Arts, 2002

[7] Zhu Yan. The construction of China's aesthetic education system [J]. Teaching Research, 2010, 5,13

[8] Zeng Fanren. Aesthetic education - is the education of people becoming "human" [J]. Modern Chinese and Western education art comparison and dialogue, 2008

[9] Shi Yixiu. The significance of aesthetic education in contemporary higher education [J]. Jiangsu Higher Education, 2007,2 